\title{
Cherry leaf spot incidence on 12 sweet cherry cultivars in integrated production
}

\author{
Vámos, A. \& Holb, I.J. \\ Centre of Agricultural Sciences, Institute of Horticulture, University of Debrecen 138 Böszörményi St., \\ 4032 Debrecen, Hungary
}

\begin{abstract}
Summary: The aim of this study was to evaluate the cherry leaf spot (CLS) incidence on 12 sweet cherry cultivars in integrated sweet cherry production in three consecutive years from 2010 till 2012. Assessed cultivars (cvs.) were 'Aida', 'Axel', 'Biggareau burlat', 'Blaze Star', 'Celeste', 'Germersdorfi 3', 'Izabella', 'Katalin', 'Krupnoplodnaja', 'Linda', 'Sunburst', 'Vera' Results showed that year had an essential effect on the CLS disease incidence. Cultivars showed great differences within years. Cultivar 'Celeste' showed the lowest disease incidence on leaves in all years lower than 10\%. The largest disease incidence on leaves was on cv. 'Sunburst' in 2010, on cv. 'Germersdorfi 3'in 2011 and on cv. 'Axel' in 2012. Disease incidence on these cultivars ranged between 10 and $25 \%$.
\end{abstract}

Keywords: cherry leaf spot, Blumeriella jaapii, integrated, culivars

\section{Introduction}

Cherry leaf spot (Blumeriella jaapii (Rehm) Arx) significantly reduces profits for sour cherry growers in Hungary in every humid year (e.g. Kaszonyi, 1966; Glits, 1962; Benedek et al., 1990; Pedersen \& Lrschenkohl, 1997; Holb, 2002; Jenser \& Véghelyi, 2003; Holb \& Veisz, 2005; Király \& Szentpéteri, 2006; Holb et al., 2010). Cherry leaf spot causes defoliation by midsummer, which results in soft, poorly colored fruit that are low in soluble solids. Early defoliation delays acclimation of fruit buds and wood to cold temperatures in the fall, increases tree mortality during severe winters, and reduces fruit bud survival and fruit set the following year (Kaszonyi, 1966; Howell \& Stackhouse, 1973; Jenser \& Véghelyi, 2003; Holb \& Veisz, 2005; Holb, 2009). A combination of biological, economic, and regulatory factors puts sour cherry industry in a precarious position regarding disease management. Managing leaf spot in Hungary typically requires five to seven fungicide applications per year, starting at about the time of petal fall and continuing until leaf fall (Jenser \& Véghelyi, 2003; Holb \& Veisz, 2005; Holb et al., 2010, 2011).

CLS is economically important on sweet and sour cherry but also affects almond, dwarf Russian almond, apricot, mahalen, chokecherry, cherry laurel and wild plums (Kaszonyi, 1966). In case of sweet cherry Benedek et al. (1990) demonstrated that cv. Germersdorfi is the least, while cv. Bigarreau Burlat is the most susceptible cultivar. Studies on rootstocks for sweet and sour cherry showed that selections of Sajmeggy C-500, Sajmeggy SL-64, MxM97 and MxM-14 have considerable resistance to leaf spot (Hrotkó, 1997). In a recent research, Király \& Szentpéteri
(2006) showed that the least sensitive cultivar was Linda while the most sensitive cultivars were Biggareau Burlat and Solymári to cherry leaf spot In the international literature, Sjulin et al. (1989) showed that cultivars Yellow Glass, Schmidt andEmperor Francis sweet cherries were the lowest and Montmorency sour cherry and Krassa Severea duke cherry were the greatest in disease defoliation caused by B. jaapii among 25 cultivars tested in the field. Christov et al.(2008)showed that Elite No 5645 is a very early ripening and productive cultivar. The cultivar produces a good fruit mass and is only moderately susceptible to cherry leaf spot (Blumeriella jaapii). Cultivar Ranochnaya had very low susceptibility to cherry leaf spot, whereas cultivars Sovetskaya, Merchant and Bing were highly susceptible to cherry leafspot. Holb (2009) demostrated a literature review on host susceptibility of cherry cultivars to CLS including sweet cherry cultivars.

The aim of this study was to evaluate the cherry leaf spot (CLS) incidence on 12 sweet cherry cultivars in integrated sweet cherry production in three consecutive years from 2010 till 2012.

\section{Materials and Methods}

The study was performed at University of Debrecen, Pallag Experimental Fruit Station in a sweet cherry orchards planted in spring of 2000. Trees were spaced $2 \times 5 \mathrm{~m}$ and grafted on Prunus mahaleb. 12 cultivars were used for CLS assessments: 'Aida', 'Axel', 'Biggareau burlat', 'Blaze Star', 'Celeste', 'Germersdorfi 3', 'Izabella', 'Katalin', 'Krupnoplodnaja', 'Linda', 'Sunburst', 'Vera'. 
Sparys against CLS followed the Hungarian Integrated Fruit Protection guidelines. At dormant bud stage copper hydroxide was used then during the season 3 additional sprays were applied with tebuconazole, pyraclostrobin, captan and dodine active ingredients. The last spray was applied in august with copper in each year.

The precipipation was different in the three year (Figure 1). The year 2011 was relatively rainy compared to the other two years.

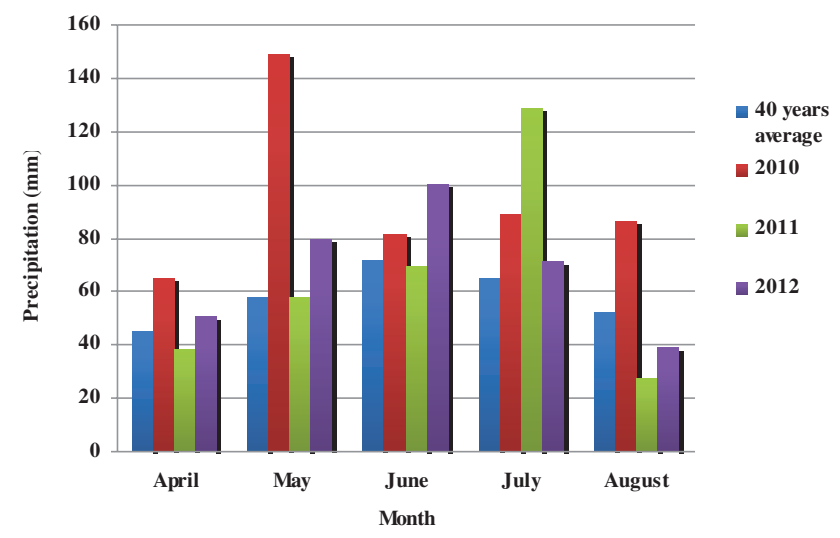

Figure 1: Precipitation (mm) from April to August (Debrecen-Pallag, 20102012)

Assessment were made in autumn of each year: 1317 September 2010, 12-16 September in 2011 and 10-15 September in 2012. Each tree of the selected cultivars were assessed. Threes were divided into four parts and 25 leaves were assessed in each quarter of the tree. Disease index was used for assessing the disease (Table 1).

Table 1: Disease index for assessing cheryy leaf spot incidence

\begin{tabular}{|c|c|}
\hline Disease index & Level of disease (\%) \\
\hline $\mathbf{0}$ & 0 \\
\hline $\mathbf{1}$ & $0-10$ \\
\hline $\mathbf{2}$ & $10-25$ \\
\hline $\mathbf{3}$ & $25-40$ \\
\hline $\mathbf{4}$ & $40-70$ \\
\hline $\mathbf{5}$ & $70<$ \\
\hline
\end{tabular}

Cultivars were sorted into three disease index groups (low, moderate, high) for all years. Group 1: disease index lower then 0,6, group 2: disease index between 0.6-1.0 and group 3: disease index higher than 1.

\section{Results and Discussion}

In 2010, the weather was not very favorable for CLS epidemics. The cultivar 'Celeste' showed the lowest disease incidence on leaves in this year which was below 5\% (Figure 2). The largest disease incidence on leaves was on cv. 'Sunburst' in 2010 which was above $10 \%$.

In 2011, the weather was favorable for CLS epidemics. Again, cultivar 'Celeste' showed the lowest disease incidence on leaves in this year which was again below 5\% (Figure 2). The largest disease incidence on leaves was on cv. 'Germersdorfi 3'in 2011 which was above 15\%. In this year most cultivars showed larger than $10 \%$ disease incidence by September.

In 2012, the weather was the least favorable for CLS epidemics. Again, cultivar 'Celeste' showed the lowest disease incidence on leaves in this year which was again below 5\% (Figure 2). The largest disease incidence on leaves was on cv. 'Axel' in 2012 which was reached 10\%. In this year, disease incidence was below $10 \%$ for all cultivars by September.

According to our results none of the cultivars were resisitant to CLS. As an average of the three years, disease incidence was low on cv. 'Celeste', moderate on cvs. 'Izabella', 'Vera', 'Aida', 'Linda', 'Krupnoplodnaja' and 'Axel', high on 'Biggareau burlat' és a 'Sunburst'.

Benedek et al. (1990) demonstrated that cv. Germersdorfi is the least susceptible to CLS which is contrast to our results, while cv. 'Bigarreau Burlat' was also considered as one of the most susceptible cultivars to CLS as it was also in our study. Similarly to our results Király \& Szentpéteri (2006) also showed that one of the most sensitive cultivars were 'Biggareau Burlat' and 'Sunburst' to cherry leaf spot.

\section{Acknowledgements}

The study was supported by the NKTH programme (OM-00227/2008) and by the research programme of OTKA (K 78399) as well as by a János Bolyai Research Fellowship.

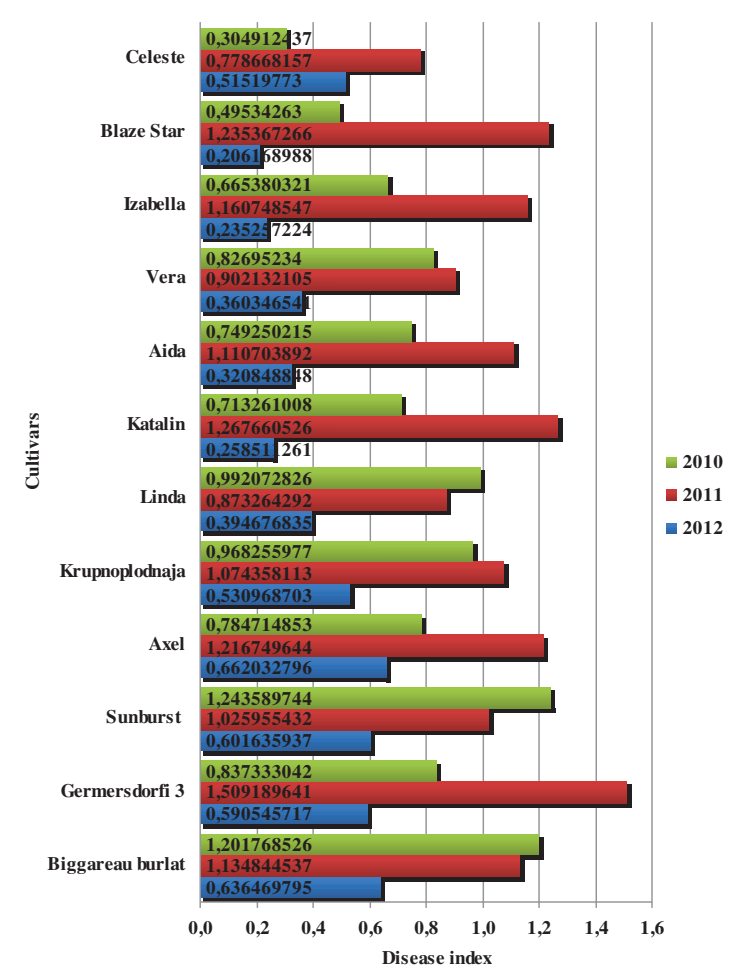

Figure 2: Disease index (0-5) of cherry leaf spot incidence for 12 sweet cherry cultivars (Debrecen-Pallag, 2010-2012) 


\section{References}

Benedek,P., Nyéki,J. \& Vályi, I. (1990): Csonthéjas gyümölcsfajták érzékenysége a fontosabb kórokozókkal és kártevőkkel szemben - A fajtaspecifikus növényvédelmi technológia kidolgozása. Növényvédelem 26 (1): 12-31.

Christov, N., Borovinova, M. \& Borisova, A. (2008): Results of the study of new sweet cherry cultivars and elites in Kyustendil Region, Bulgaria. Acta Horticulturae. 795: 97-101.

Glits, M. (1962): A cilindrospóriumos betegség hazai előfordulása termőfákon. Kertészet és Szőlészet, 24: 18-19.

Holb, I. (2002): Blumeriellás levélfoltosság. 173-175. In: Radócz, L. (ed.):A héjasok növényvédelme. Szaktudás Kiadóház, Budapest, pp. 256.

Holb, I. (2009): Some biological features of cherry leaf spot (Blumeriella jaapii) with special reference to cultivar susceptibility. International Journal of Horticultural Science, 15 (1-2): 91-94.

Holb I.J., Lakatos, P., Abonyi, F. (2010): Some aspects of disease management of cherry leaf spot (Blumeriella jaapii) with special reference to pesticide use. International Journal of Horticultural Science, 16 (1): 45-49.

Holb, I.J., Vámos, A., Lakatos, P., Gáll, J.M. \& Abonyi, F. (2011): Some aspects of reduced disease management against Blumeriella jaapii in sour cherry production. International Journal of Horticultural Science, 17 (1-2): 49-53.
Holb, I. \& Veisz, J. (2005): A cseresznye és a meggy jelentősebb kórokozói. 138-144. In: Holb I. (ed.): A gyümölcsösök és a szőlő ökológiai növényvédelme. Mezőgazda Kiadó, Budapest, pp. 341.

Howell, G. S., \& Stackhouse, S. S. (1973): The effect of defoliation time on acclimation and dehardening in tart cherry (Prunus cerasus L.). Journal of the American Society for Horticultural Sciences, 98: 132-136.

Hrotkó, K. (1997): Alanyfajták. p. 134-159. In: Soltész M. (ed.): Integrált gyümölcstermesztés. Mezőgazda Kiadó, Budapest

Jenser, G. \& Véghelyi, K. (2003): A cseresznye és a meggy növényvédelme. pp. 259-295. In: Hrotkó K. (szerk.) Cseresznye és meggy. Mezőgazda Kiadó, Budapest, p. 419.

Kaszonyi, S. (1966): Life cycle of Blumeriella jaapii infecting stone-fruit. Acta Phytopathologica Academica Scientia Hungarica, 1: $93-100$.

Király, K. \& Szentpéteri T. (2006): Blumeriella jaapii /Rehm/ v. /Arx/ infection of some sweet cherry cultivars in two years with different precipitation conditions. International Journal of Horticultural Sciences, 12 (3): 47-49.

Pedersen, H. L. \& Lrschenkohl L. (1997): Implementation of a warning system to control cherry leaf spot (Blumeriella jaapii) under European conditions. Gartenbauwissenschaft, 62: 197-201.

Sjulin, T. M:, Jones A. L. \& Andersen, R. L. (1989): Expression of partial resitance to cherry leaf spot in cultivars of sweet, sour, duke, and European ground cherry. Plant Disease, 73: 56-61. 